\title{
SRI LANKA IN 2000
}

\author{
The Politics of Despair
}

\section{Lawrence Sáez}

The tragedy of Sri Lanka reached a harrowed equilibrium in the year 2000. Its prospects for bright economic growth and semblance of stable democratic rule have taken place against the backdrop of a protracted civil war, which dominates political discourse in the country. For the time being, it appears that there is a growing southern consensus favoring resolution to the civil war. At the same time, there are some indications that Tamil rebel groups may be ready to negotiate with the Sri Lankan government. However, the stasis in the military activities of the Liberation Tigers of Tamil Eelam (LTTE) and government forces revealed that Sri Lanka's civil war is as virulent as it is intractable.

\section{The Civil War and Its Improbable Resolution}

The embers of Sri Lanka's civil war continued to burn confidently. The LTTE remains the most serious challenge to government troops. The war is waged on two fronts: the military conflict on the Jaffna Peninsula and the war of propaganda for international consumption. This year, neither side could claim convincing victories on the military facet of the conflict. The most striking success of the LTTE was its takeover of the main army garrison at Elephant Pass on April 21. This victory has given the LTTE control over the gateway to the Jaffna Peninsula and, psychologically, was also an important

Lawrence Sáez is Assistant Research Political Scientist at the Institute of East Asian Studies and Visiting Scholar at the Center for South Asia Studies at the University of California, Berkeley. He is also Associate Editor for South Asia at Asian Survey.

Asian Survey, 41:1, pp. 116-121. ISSN: 0004-4687

(C) 2001 by The Regents of the University of California/Society. All rights reserved.

Send Requests for Permission to Reprint to: Rights and Permissions, University of California Press, Journals Division, 2000 Center St., Ste. 303, Berkeley, CA 94704-1223. 
step in its professed strategy to recapture Jaffna. ${ }^{1}$ By the end of the year, though, Sri Lankan government forces have made significant inroads into the highway from Jaffna to the Vanni region.

The civil war is also a war of propaganda. While the war has been a cata$\log$ of human cruelty, the absence of a truly free press and the mordancy of LTTE emissaries have created a scarcity of credible reports on the war's developments. Most of the international attention has focused on the suicide bombings of civilian targets. On January 8, 2000, 12 people were killed in a suicide bomb attack outside the prime minister's office. On June 7, a suicide bomber killed the Industries Minister, C. V. Gooneratne. Altogether the attack killed 25 people. The LTTE is also suspected of carrying out a suicide bombing attack at an eye clinic in Colombo. In addition to these terrorist acts perpetrated by Tamil militants, the LTTE has been accused of conscripting child soldiers. The Sri Lankan government and international human rights organizations have reported that some of the LTTE combatants in the civil war are as young as 10 years old.

In contrast, the unconscionable behavior by some Sri Lankan government forces has been less widely reported. One of the most shocking events during the year was the murder of young Tamil detainees on October 25. Growing international concern over the treatment of LTTE combatants and the constant allegations of torture by police and security forces have prompted Sri Lanka's attorney general to establish a special investigative task force.

One positive element in this miasma is that Norway has agreed to play the role of negotiation facilitator between the LTTE and Sri Lanka's government. The key player in the negotiations has been Erik Solheim, special advisor to Norway's foreign minister and formerly the controversial leader of the Norwegian Socialist Left Party. Following the LTTE's victory at Elephant Pass, its leader, Vellupullai Prabhakaran, had cryptically expressed some interest in the negotiation process. In order to participate in the negotiations, LTTE's emissaries proposed a temporary cease-fire that would allow over 35,000 government troops to evacuate the Jaffna Peninsula. The government quickly dismissed the LTTE demands and instead called for a unilateral cease-fire by the LTTE and rejected the proposal to withdraw any government troops from the Jaffna Peninsula.

Following a November meeting between Solheim and Prabhakaran, though, the LTTE agreed to a one-month, unilateral cease-fire. On December 21, the LTTE ceased hostilities in what it claimed to be a goodwill measure to facilitate the negotiations. In reality, the prospects for the success of this

1. In November 1999, the LTTE announced the launching of "Operation Unceasing Waves." This operation aims to recapture the city of Jaffna, which has been under government control since 1995. Control of Jaffna is perceived by many to be of critical importance to prevent LTTE success in the rest of the peninsula. 
latest round of negotiations are slim. Over the past 16 years, previous efforts to negotiate a settlement have only served to exacerbate the conflict. Although the government has tentatively expressed an interest in opening up some negotiations with the LTTE, the spirit of negotiation is currently not the most congenial. In an interview with the French daily, Le Point, Sri Lankan President Chandrika Bandaranaike Kumaratunga claimed that Prabhakaran, "has the mentality of an Adolf Hitler. He is a megalomaniac. He finds much pleasure in killing and destroying." In Kumaratunga's assessment, "what the LTTE wants is to torpedo the negotiations." Following the LTTE's unilateral cease-fire, the government responded with a massive offensive against LTTE sites. Although the veracity of the Ministry of Defense reports is sketchy, it had claimed to have recaptured 35 square kilometers in the Chavakachcheri area. It is doubtful that Kumaratunga's peculiar opening response to LTTE overtures will lead to fruitful negotiations.

\section{Dynastic Politics and the Distress of Democratic Institutions}

The year 2000 marked the twilight of one female political figure and the consolidation of another. For health reasons, Sirimavo R. D. Bandaranaike resigned as prime minister. Mrs. Bandaranaike had been a prominent figure in Sri Lankan politics since her husband's assassination in 1959. Her replacement, Ratnasiri Wickramanayake, was sworn in on August 10, 2000. Bandaranaike died a few months afterward on October 10. This year also marked the consolidation of Mrs. Bandaranaike's daughter, President Chandrika Bandaranaike Kumaratunga, and her first year in office as an incumbent. In December 1999, Kumaratunga's People's Alliance (PA) had received over $51 \%$ of the vote for the presidency. Her challenger, Ranil Wickramasinghe, from the United National Party (UNP) received $42 \%$ of the vote.

In order to conciliate differences with the UNP, Kumaratunga conducted 15 rounds of talks with Wickramasinghe. By June 2000, Kumaratunga and UNP leaders agreed that the best way to resolve the conflict in the northeast was by way of a referendum to be carried out in the Triconmalee and Batticaloa Districts. The tentative agreement between the PA and the UNP called for the establishment of an interim council to administer the recently merged northeastern region. However, the proposed interim council would not include participation by the LTTE.

Having survived an assassination attempt in December 1999, Kumaratunga's biggest challenge in 2000 was to carry through her legislative agenda in the midst of a hotly contested parliamentary election. Sri Lanka's Consti-

2. Le Point, April 17, 2000. 
tution calls for the dissolution of Parliament prior to the general election. Taking advantage of this provision, Kumaratunga extravagantly decided that the most significant legislative action by her administration should be carried out on the eve of the dissolution of Parliament. The swift introduction of the Constitutional Reforms Bill in Parliament created an uproar in political circles. The bill aimed to replace the existing Constitution by providing an increase in regional power sharing and administrative decentralization. The controversy over the bill arose because of the tenuous balance between increased decentralization and autonomy. Likewise, Kumaratunga's popularity was tested with the promulgation of the Public Security Ordinance. The emergency ordinance has only been invoked three times in Sri Lanka's history. This year's promulgation sparked protests because it provides security forces with sweeping powers to conduct arrests and seizures.

Kumaratunga's proposed constitutional reforms failed to obtain the necessary two-thirds majority. By staking her administration to such controversial legislation, Kumaratunga threatened the flimsy consensus between the governing alliance and the opposition over the fate of the northeast. Moreover, the tussles also affected the stability of the governing coalition. For instance, the leader of the Sri Lanka Muslim Congress (SLMC), M. H. M. Ashraff, announced that he was withdrawing support for the PA. Fortuitously for Kumaratunga, Ashraff's helicopter mysteriously crashed the same day of his announcement.

The PA encountered pertinacious opposition during the 2000 parliamentary general election. Invariably, the centerpiece of the UNP's campaign during the election was Kumaratunga's rashly promoted Constitutional Reforms Bill. Held on October 10, the election was predictably marred by incidents of ballot stuffing, voter intimidation, and violence at certain poll centers. For instance, 24 people were killed at an election rally in Muttur.

Even though 29 parties participated in the activities, Sri Lanka's electoral landscape continued to be dominated by the PA and the UNP. Although preelection polls had predicted a close election, the PA and the UNP received $45 \%$ and $40 \%$ of the vote, respectively. As such, the allocation of seats in the Parliament is split mostly between the two main parties: the PA holds 107 parliamentary seats, while the UNP holds 89 seats. At first glance, the parliamentary general election could be perceived as a ratification for Kumaratunga's proposed constitutional reforms. However, although the PA clearly emerged as the largest party in Parliament, it failed to gain a majority of the seats.

Since the PA fell six seats short of obtaining a majority, Kumaratunga's administration will have to seek the assistance of contentious third parties. Ideologically divergent parties such as the radical Janatha Vimukthi Peramuna (JVP), the Muslim coalition National Unity Alliance (NUA), and 
Sihala Urumaya (SU) hold 15 seats among them. Although the SLMC had formally split from the governing alliance prior to the election, it later offered conditional support to the PA as long as the constitutional reforms are carried out quickly. At the same time, moderate Tamil parties, such as the Tamil United Liberation Front (TULF) and the Eelam People's Democratic Party (EPDP), have failed to provide conclusive electoral support to the governing coalition. Therefore, the current electoral scenario suggests that Kumaratunga will have to negotiate treacherous legislative waters.

\section{Foreign Policy and the Economy}

As an island economy, Sri Lanka is heavily dependent on external trade. Moreover, its future economic prospects are intimately tied to an expansive foreign policy with its neighbors. As has been the case in the past, India continues to play a disproportionate role on Sri Lanka's economy. For the time being, the Indo-Lanka Free Trade Agreement (signed on December 28, 1998) appears to be Sri Lanka's most promising trade link. The agreement provided a substantial reduction of tariffs and import quotas between both countries. In February 2000, there were letters of exchange between Sri Lanka's Ministry of Finance and Planning and India's Ministry of Commerce and Industry. These letters purported to cement some of the discussion carried out in relation to tea and cement imports.

Sri Lanka's ability to show some gains in the midst of a civil war must be attributed to its economic liberalization. Sri Lanka's domestic economic indicators saw a revival in the year 2000. According to Sri Lanka's central bank, the country's gross domestic product (GDP) grew impressively at $6.3 \%$ and $7.4 \%$ during the first two quarters of this year, respectively. This percentage replicates Sri Lanka's rapid economic growth during the 1997-98 period and far exceeded the pitiful 4.3\% GDP growth in 1999. The gradual recovery of the East Asian economies has been largely credited for Sri Lanka's rebound. Sri Lanka's domestic accomplishments, however, have been tempered by a troubling rise in inflationary pressures.

Sri Lanka's foreign minister, Lakhsman Kadirgamar, has become the most visible supporter of economic liberalization. Under his tutelage, Sri Lanka's indicators in its external sector also provided some measure of optimism. The first quarter of the year 2000 witnessed a dramatic $24 \%$ increase in export volume. Imports also grew impressively by nearly $30 \%$ during the same period. The optimism in the economic front ought to be tempered by Sri Lanka's continuing structural problems. Its economy is strongly dominated by labor intensive industries and natural resources.

Sri Lanka, like most developing countries, has tried to attract foreign investment toward physical infrastructure projects. In the year 2000, the Board of Investment either approved or implemented up to two billion dollars in 
infrastructure investment. The Board of Investment's landmark occurred when two memorandums of understanding for the development of two power plants in Anaradhapura and Matara were signed with leading multinationals. ${ }^{3}$

Sri Lanka's most promising economic prospect, though, is in the area of information technology (IT). Following the example of India's high technology corridor, Sri Lanka set up its first incubator for emerging IT firms in July. Growth in this capital-intensive industry is certain to be linked to India. In turn, Sri Lanka's Tamil minority is likely to benefit from the growth in the information technology sector. Paradoxically, the growth in this sector may spell a downturn in civil cohesion.

3. See Board of Investment website at <www.boisrilanka.org/boihome/bii/htm $>$ [accessed December 20, 2000]. 